\section{Taxonomic} Note

\author{
Correspondence \\ B. J. Tindall \\ bti@dsmz.de
}

\title{
Challenging Opinion 83
}

\author{
B. J. Tindall
}

DSMZ - Deutsche Sammlung von Mikroorganismen und Zellkulturen GmbH, Inhoffenstrasse 7B, 38124 Braunschweig, Germany

\begin{abstract}
The Judicial Commission has ruled that subgenus names within the genus Moraxella should be considered to have been included on the Approved Lists, together with the corresponding species names within these subgenera. Closer examination of the facts, including the wording of the relevant passages in the Code and the original publication in which these names are included, together with information that has subsequently come to light, indicates that there is good cause to re-examine the facts on which this Opinion is based.
\end{abstract}

The deliberations at the meeting of the Judicial Commission held in San Francisco, USA, in 2005 are the basis of the formulation of Opinion 83 which deals with the valid publication of the subgenus names Moraxella subgen. Moraxella and Moraxella subgen. Branhamella and the species contained within these subgenera (Judicial Commission of the International Committee for Systematics of Prokaryotes, 2008; Tindall et al., 2008). This Opinion is based on the facts as reported by Euzéby in the original Request for an Opinion (Euzéby, 2001). However, the discussions centred largely on the date of publication of the names and whether these names should have appeared on the Approved Lists of Bacterial Names (Skerman et al., 1980, 1989). During the course of a further evaluation of the facts, it would appear that the Judicial Commission has overlooked one critical element: do any of the publications mentioning these names allow them to be regarded as meeting the criteria for valid publication? Two important issues arise. The first is the absence of these names on the Approved Lists of Bacterial Names, including the amended edition (Skerman et al., 1980, 1989), despite their publication in the International Journal of Systematic Bacteriology (IJSB) in 1979 (Bøvre, 1979). Technically, such names would qualify for consideration on the Approved Lists according to Rule 24a, Note 1 (Lapage et al., 1975). These names are considered to have been validly published in both Bergey's Manual of Systematic Bacteriology (Bøvre, 1984a) as well as in the index of Moore et al. (1985). However, these two publications do not effect valid publication and cannot be considered, other than indicating that they add to the confusion. The article in Bergey's Manual of Systematic Bacteriology (Bøvre, 1984a) also does not provide a formal description of the subgenera. Euzéby (2001) also correctly draws attention to the inclusion of the subgenus names on Validation List 15 (Bøvre, 1984b) and to the omission of the corresponding species names within the subgenera. The second issue is which criteria are included in the effective publications in support of valid publication? The criteria to be taken into consideration are those laid down by the 1975 revision of the International Code of Nomenclature of Bacteria (the Code; Lapage et al., 1975). Although there have been subsequent changes to the Code, the critical changes to Rule 27 are not retroactive. The two key points are the typification of the subgenera and the corresponding species, together with an accompanying description. The original publication in 1979 (Bøvre, 1979) does not make reference to the types of the subgenera and does not include any formal descriptions, apart from dividing the groups of species into lists of 'rodshaped organisms' and 'coccal organisms'. The species names created within the subgenera are typified, but there is no reference to the description of the majority of the species, either directly or via reference to an earlier publication. Thus, any subsequent reference to these subgenus names, even if the names are considered to have been overlooked in the compilation of the Approved Lists of Bacterial Names (Skerman et al., 1980, 1989), must take into account whether these names are accompanied by typification and a description of the appropriate taxon.

The major issue with regards to the species names is the lack of clear descriptions (Bøvre, 1979). This effectively identifies the interpretation in both Bergey's Manual of Systematic Bacteriology Bøvre (1984a), as well as the index of Moore et al. (1985), as being incorrect, since the proposed new names are clearly not in accord with the Rules of the Code (Lapage et al., 1975, 1992). It is interesting to note that in the index of Moore et al. (1985), the authority of the species names generally does not refer to the work of Bøvre (1979), although their publication in that work is cited. It would also seem to be logical to conclude that if the subgenus names were not validly published, then nor were the accompanying species names (combinations) within these subgenera.

Inclusion of the subgenus names on Validation List 15 (Bøvre, 1984b) makes reference to appropriate types, but this does not solve the problem of whether a description is given. This would imply that despite inclusion on this list, the names may not meet the criteria laid down for valid 
publication. Furthermore, the corresponding species combinations are not included, meaning that there are no validly published species names included in these subgenera. Can a name be typified in the absence of a corresponding validly published species name? The Approved Lists of Bacterial Names (Skerman et al., 1980, 1989) includes both the genus names Moraxella and Branhamella, making reference to Bergey's Manual of Determinative Bacteriology, 8th edn (Buchanan \& Gibbons, 1974) as the source of the descriptions of these two genera, or rather, indirectly to the articles included in that volume (Lautrop, 1974; Reyn, 1974). However, the Approved Lists of Bacterial Names (Skerman et al., 1980, 1989) typifies and makes reference to a description of the genus Branhamella and the species included in the genus as a separate taxon, whereas the genus Moraxella includes Branhamella catarrhalis under its homotypic synonym Moraxella catarrhalis, an example of synonymous names appearing on the Approved Lists. The list of species names included under the genera Moraxella and Branhamella (Skerman et al., 1980, 1989) is also more comprehensive than those listed under the subgenus names Moraxella subgen. Moraxella and Moraxella subgen. Branhamella (Bøvre, 1979), creating potential problems for the nomenclature of a taxonomy that attempts to take these subgenus names into consideration.

A further element of confusion is added by Validation List 15 including the name Moraxella cuniculi (Bøvre \& Hagen, 1984), while the effective publication gives the name as Moraxella (Branhamella) cuniculi (Bøvre \& Hagen, 1981). Strangely, this publication only deals with the genus Moraxella and Moraxella subgen. Branhamella, no formal mention being made of the name Moraxella subgen. Moraxella. This is a paradox since the name Moraxella subgen. Branhamella can only be used if the genus Moraxella is indeed formally divided. However, it would appear that neither subgenus name was validly published at the time that this name was effectively published in 1981 .

Sneath (2005) has also indicated that 'there were also problems associated with the ranks of subgenera and subspecies, because such names cause a major increase in the complexity of the Rules. In the event few were listed, and there has been no complaint on this'. In fact, names of subgenera were not included in the Approved Lists of Bacterial Names, indicating that this was deliberate and not just an oversight.

Recent taxonomic treatments have dealt with members of the genera Branhamella and Moraxella subgen. Branhamella (and Moraxella subgen. Moraxella) as members of the genus Moraxella, suggesting that a separation of the species included into either subgenera or distinct genera is no longer supported (Juni \& Bøvre, 2005). However, the 16S rRNA gene sequence data indicate that while the members of the genus Moraxella examined (with the exception of the species Moraxella atlantae and Moraxella osloensis) are to be considered to be mono- phyletic, there are also subdivisions that follow simple criteria, such as cell morphology, indicating that such monophyletic groups can, indeed, be further divided into more than one monophyletic group. In particular, the species Moraxella caviae, M. cuniculi and M. catarrhalis, which have characteristic cell morphology and planes of division, group separately from the species containing rodshaped strains. The species Moraxella saccharolytica, Moraxella lincolnii, Moraxella boevrei and Moraxella caprae are not considered.

While Opinion 83 attempted to deal with the valid publication of subgenus names within the genus Moraxella and species names within these subgenera, important facts may not have been taken into consideration. The critical issue is that of whether these names meet the criteria laid down for valid publication. Thus, according to Rule 27 of the Code (Lapage et al., 1992):

'A name of a new taxon, or a new combination for an existing taxon, is not validly published unless the following criteria are met.....

(2) The publication of the name in the IJSB is accompanied by a description of the taxon or by a reference to a previous effectively published description of the taxon....'

In the case of these two subgenus names, it is questionable whether this is the case and this could be one of the reasons (together with the absence of typification) why these names were deliberately not included on the Approved Lists. Another aspect that has not been taken into consideration is whether subgenus names were deliberately omitted (Sneath, 2005). This is in contradiction to Opinion 83, where critical facts appear to have been overlooked. The following points need to be taken into consideration:

(i) Opinion 83 does not make reference to a description for each of the subgenera or species, nor does Bøvre (1979). This could be rectified by making reference to appropriate descriptions (if they exist).

(ii) The listing in the index of Moore et al. (1985) is equally insufficient to qualify for valid publication.

(iii) Inclusion in Validation List 15 also does not cater for the descriptions of the subgenera but, more importantly, the species names within these subgenera are not included on that list or in subsequent ones.

(iv) It is evident that there are flaws associated with the way names, descriptions and types are dealt with by Bøvre (1979). If this publication does not contain information that allows inclusion of these names on the Approved Lists, then subsequent publications such as Validation List 15 are equally inadequate. If Opinion 83 has not solved the problem, then these names are certainly not validly published.

The Judicial Commission should re-examine the facts on which Opinion 83 is based and either confirm or revise that 
Opinion. Challenging an Opinion is in accord with Appendix 8 of the Code (Lapage et al., 1992).

\section{References}

Bøvre, K. (1979). Proposal to divide the genus Moraxella Lwoff 1939 emend. Henriksen and Bøvre 1968 into two subgenera, subgenus Moraxella (Lwoff 1939) Bøvre 1979 and subgenus Branhamella (Catlin 1970) Bøvre 1979. Int J Syst Bacteriol 29, 403-406.

Bøvre, K. (1984a). Genus II. Moraxella Lwoff 1939, 173 emend. Henriksen and Bøvre $1968391^{\mathrm{AL}}$. In Bergey's Manual of Systematic Bacteriology, vol 1, pp. 296-303. Edited by N. R. Kreig \& J. G. Holt. Baltimore: Williams and Wilkins.

Bøvre, K. (1984b). Branhamella subgen. nov. and Moraxella subgen. nov. In Validation of the Publication of New Names and New Combinations Previously Effectively Published Outside the IJSB, List no. 15. Int J Syst Bacteriol 34, 355-357.

Bøvre, K. \& Hagen, N. (1981). The family Neisseriaceae: rod-shaped species of the genera Moraxella, Acinetobacter, Kingella, and Neisseria, and the Branhamella group of cocci. In The Prokaryotes: a Handbook on Habitats, Isolation and Identification of Bacteria, pp. 1506-1529. Edited by M. P. Starr, H. Stolp, H. G. Trüper, A. Balows \& H. G. Schlegel. Berlin: Springer-Verlag.

Bøvre, K. \& Hagen, N. (1984). Moraxella cuniculi sp. nov. In Validation of the Publication of New Names and New Combinations Previously Effectively Published Outside the IJSB, List no. 15. Int J Syst Bacteriol 34, 355-357.

Buchanan, R. E. \& Gibbons, N. E. (1974). Bergey's Manual of Determinative Bacteriology, 8th edn. Baltimore: Williams and Wilkins.

Euzéby, J. P. (2001). Nomenclature of the subgenera Moraxella and Branhamella and of the nine species included in these subgenera and proposal to modify Rule 34a of the Bacteriological Code (1990 Revision). Request for an Opinion. Int J Syst Evol Microbiol 51, 19391941.

Judicial Commission of the International Committee on Systematics of Prokaryotes (2008). The subgenus names Moraxella subgen. Moraxella and Moraxella subgen. Branhamella and the species names included within these taxa should have been included on the Approved List of Bacterial Names and a ruling on the proposal to make changes to Rule 34a. Opinion 83. Int J Syst Evol Microbiol 58, 1766-1767.

Juni, E. \& Bøvre, K. (2005). Family II. Moraxellaceae Rossau, Van Landschoot, Gills and De Ley $1991317^{\mathrm{VP}}$. In Bergey's Manual of Systematic Bacteriology, 2nd edn, vol. 2, pp. 411-442. Edited by D. Brenner, N. R. Kreig \& J. T. Staley., New York, Berlin, Heidelberg: Spinger.

Lapage, S. P., Sneath, P. H. A., Lessel, E. F., Skerman, V. B. D., Seeliger, H. P. R. \& Clark, W. A. (editors) (1975). International Code of Nomenclature of Bacteria (1975 Revision). Bacteriological Code. Washington, DC: American Society for Microbiology.

Lapage, S. P., Sneath, P. H. A., Lessel, E. F., Skerman, V. B. D., Seeliger, H. P. R. \& Clark, W. A. (editors) (1992). International Code of Nomenclature of Bacteria (1990 Revision). Bacteriological Code. Washington, DC: American Society for Microbiology.

Lautrop, H. (1974). Genus II. Moraxella Lwoff 1939, 173 Nom. cons. Opin. 41 Jud. Comm. 1971, 106. In Bergey's Manual of Determinative Bacteriology, 8th edn, pp. 433-436. Edited by R. E. Buchanan \& N. E. Gibbons. Baltimore: Williams and Wilkins.

Moore, W. E. C., Cato, E. P. \& Moore, L. V. H. (1985). Index of the bacterial and yeast nomenclatural changes published in the International Journal of Systematic Bacteriology since the 1980 Approved Lists of Bacterial Names (1 January 1980 to 1 January 1985). Int J Syst Bacteriol 35, 382-407.

Reyn, A. (1974). Genus II. Branhamella Catlin 1970, 157. In Bergey's Manual of Determinative Bacteriology, 8th edn, pp. 432-433. Edited by R. E. Buchanan \& N. E. Gibbons. Baltimore: Williams and Wilkins.

Skerman, V. B. D., McGowan, V. \& Sneath, P. H. A. (1980). Approved lists of bacterial names. Int J Syst Bacteriol 30, 225-420.

Skerman, V. B. D., McGowan, V. \& Sneath, P. H. A. (editors) (1989). Approved Lists of Bacterial Names (Amended Edition). Washington, DC: American Society for Microbiology.

Sneath, P. H. A. (2005). The preparation of the Approved Lists of Bacterial Names. Int J Syst Evol Microbiol 55, 2247-2249.

Tindall, B. J., De Vos, P. \& Trüper, H. G. (2008). Judicial Commission of the International Committee on Systematics of Prokaryotes, XIth International (IUMS) Congress of Bacteriology and Applied Microbiology; Minutes of the meetings, 23, 24 and 27 July 2005, San Francisco, USA. Int J Syst Evol Microbiol 58, 1737-1745. 